\title{
Bioinformatics Study Genes Encoding Enzymes Involved in the Biosynthesis of Carotenoids Line Cassava (Manihot esculenta)
}

\author{
Mutia Anika $^{1}$, Dwi Hilda Putri ${ }^{1}$, Wahyuni ${ }^{2 *}$ \\ ${ }^{1}$ Department of Biology, Universitas Negeri Padang, Indonesia \\ ${ }^{*}$ Indonesian Institute of Sciences, Cibinong, Indonesia \\ Email : wahyu004@gmail.com
}

\begin{abstract}
Cassava (Manihot esculenta) is one of the food crops that contain high carbohydrate and is used as a raw material for various industries. Cassava also contains several types of proteins, including beta-carotene. This bioinformatics study aims to determine the similarities and differences in the enzyme encoding genes involved in carotenoid biosynthesis pathways in cassava with several plants containing beta-carotene from nucleotide sequences and encoding gene proteins carotenoids (Lcy $\alpha$ and Lcy $\beta$ ). Data on nucleotide and protein sequences were obtained through the NCBI database. Similarities and differences in nucleotide and protein sequence data are seen from the phylogenetic tree using the MEGA 7.0 program. Based on the nucleotide gene Lcy a Manihot esculenta with several plants containing beta-carotene is not related. However, based on the protein phylogenetic gene Lcy a Manihot esculenta is closely related to Durio zibenthinus. Based on the nucleotide phylogenetic tree Gen Lcy $\beta$ Manihot esculenta has the similarity with Citrus maxima. Meanwhile, phylogenetic gene protein Lcy $\beta$ Manihot esculenta has the similarity with Durio zibethinus. Based on the phylogenetic tree nucleotide sequence protein Lcy $\alpha$ and Lcy $\beta$ Manihot esculenta with several plants containing beta-carotene there were differences in similarity.
\end{abstract}

Keywords : Cassava, beta carotene, bioinformatics, nucleotide

\section{Introduction}

Cassava (Manihot esculenta) is one of the tropical and subtropical food plants of the Euphorbiaceae family from Brazil. In Indonesia, the plant is used as food because it contains a high karbohoidrat. As a staple food-producing carbohydrates, cassava ranks third after rice and maize. In addition to a lot of starch, cassava also contains several types of proteins, such as beta-carotene. In Indonesia, this plant is used as food because it contains high carbohydrate. As a staple carbohydrate-producing food, cassava ranks third after rice and corn. In addition to containing lots of starch, cassava also contains several types of proteins, including beta-carotene

Facts in epidemiology and the results showed that the carotenoids act as provitamin A and antioxidants [15]. Carotenoids are also useful to enhance the immune system and reduce the risk of degenerative diseases such as cancer, cardiovascular disease, aging and cataracts .

Beta-carotene is obtained through biosynthesis of carotenoids. There are several enzymes in the biosynthesis of carotenoids including LCY $\alpha$ and LCY $\beta$ which 
determines the formation of beta-carotene $[15 ; 1]$. The $\beta$-lycopene cyclase (LYC $\beta$ ) enzyme will catalyze the change of lycopene to beta-carotene. Meanwhile, the enzyme $\varepsilon$ lycopene cyclase (LYC $\alpha$ ) catalyzes lycopene to alpha-carotene [3].

Carotenoids are important groups of dyes (pigments) and widely distributed in living organisms. Each plant contains different levels of beta-carotene. There are several bulbous plants containing high beta-carotene, such as orange tuber sweet potato $(99 \mu \mathrm{g} /$ g), carrots (6.19-14.59 mg / $100 \mathrm{~g})$, and taro $(11,066 \mathrm{mg} / 100 \mathrm{~g})$ [1; 1]. In the cassava plant, beta-carotene content will affect the color of the tuber. White tubber cassava has lower beta-carotene content $(0.09 \mu \mathrm{g} / \mathrm{g}-0.011 \mu \mathrm{g} / \mathrm{g})$ compared to yellow tuber cassava $(0.018 \mu \mathrm{g} / \mathrm{g}-0.026 \mu \mathrm{g} / \mathrm{g})$ [2].

One strategy that can be done to improve the quality of cassava (especially in terms of beta-carotene content) is through plant breeding. To increase the beta-carotene content of cassava it is important to understand the beta-carotene metabolic pathway properly. This article aims to analyze bioinformatic sequences of nucleotide genes as well as Lcy $\alpha$ and Lcy $\beta$ proteins in wood tuber plants compared to plants that produce other betacarotene.

\section{Methods}

Bioinformatic analysis of Lcy $\alpha$ and Lcy $\beta$ gene sequences was carried out on nucleotide sequences and cassava protesters and some plants that had similar genes. The gen-genes nucleotide sequences analyzed were obtained from data stored in the NCBI gene bank. Plants containing beta-carotene analyzed in this article can be seen in Table 1.

Table 1. Lcy $\alpha$ and Lcy $\beta$ cassava gene sequences and some plants containing betacarotene at NCBI

\begin{tabular}{ccc}
\hline Spesies & Accesion Number Lcy $\boldsymbol{\alpha}$ & Accesion Number Lcy $\beta$ \\
\hline Manihot esculenta & XM_021741250.1 & GU120074.1 \\
Beta vulgaris & XM_010698239.2 & XM_010674673.2 \\
Daucus carota & NM_001329163.1 & NM_001329160.1 \\
Raphanus sativus & XM_018617481.1 & XM_018636523.1 \\
Solanum lycopersicum & NM_001247408.2 & NM_001247516.2 \\
Actinidia deliciosa & - & FJ427509.1 \\
Ananas comosus & XM_020250148.1 & XM_020254027.1 \\
Carica papaya & XM_022046324.1 & FJ599643.1 \\
Citrullus lanatus & - & EF183522.1 \\
Durio zibethinus & XM_022896007.1 & XM_022891903.1 \\
Musa acuminata & XM_009406869.2 & XM_009419826.2 \\
Fragaria ananassa & JN979374.1 & JN979375.1 \\
Malus domestica & XM_008389970.2 & XM_008394164.2 \\
Citrus maxima & AY994158.1 & AY217103.3 \\
Vitis vinifera & NM_001281164.1 & JQ319643.1 \\
Momordica Charantia & XM_022298937.1 & XM_022298211.1 \\
Cucurbita maxima & XM_023110273.1 & XM_023110491.1
\end{tabular}

11 IEKSAKTA: Berkala IImiah Bidang MIPA 
The Lcy $\alpha$ and Lcy $\beta$ protein sequences were obtained by translating the Lcy $\alpha$ and Lcy $\beta$ gene nucleotide sequences using BioEdit software. Phylogenetic trees constructed based on nucleotide sequences and gene proteins Lcy $\alpha$ and Lcy $\beta$ i using MEGA 7.0 software

\section{Results and Discussion}

Carotenoids are precursors of vitamin A found in various plants. Researchs on levels carotenoids, carotenoid biosynthesis, proteins and even bioinformatics analysis such sequences of the gen has been carried out on several plants. Bioinformatics data in the form of nucleotide sequences, genomes and plant proteins containing carotenoids have been widely uploaded and accessed at NCBI including Manihot esculenta. Analysis of the sequences and protein genes encoding enzymes involved in the Manihot esculenta carotenoid biosynthesis pathway have been carried out. This analysis aims to find out the similarities and differences in carotenoid sequences and proteins Manihot esculenta with several plants containing the same carotenoids.

Each bioinformatics data is obtained from the NCBI website. The results of the analysis can be seen through the phylogenetic tree that was formed with the help of MEGA 7 software. As in expand in Fig1.

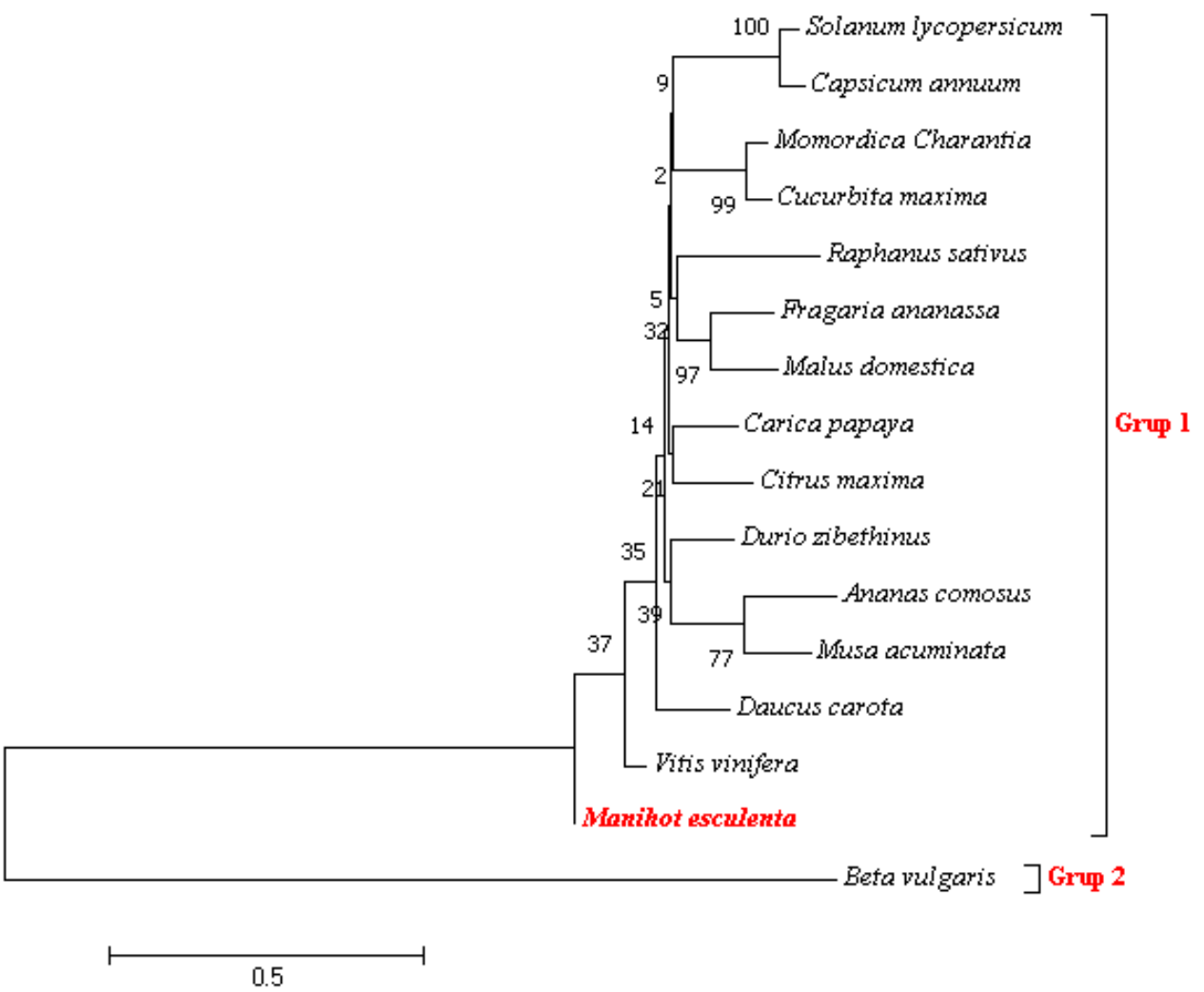

12 IEKSAKTA: Berkala IImiah Bidang MIPA 


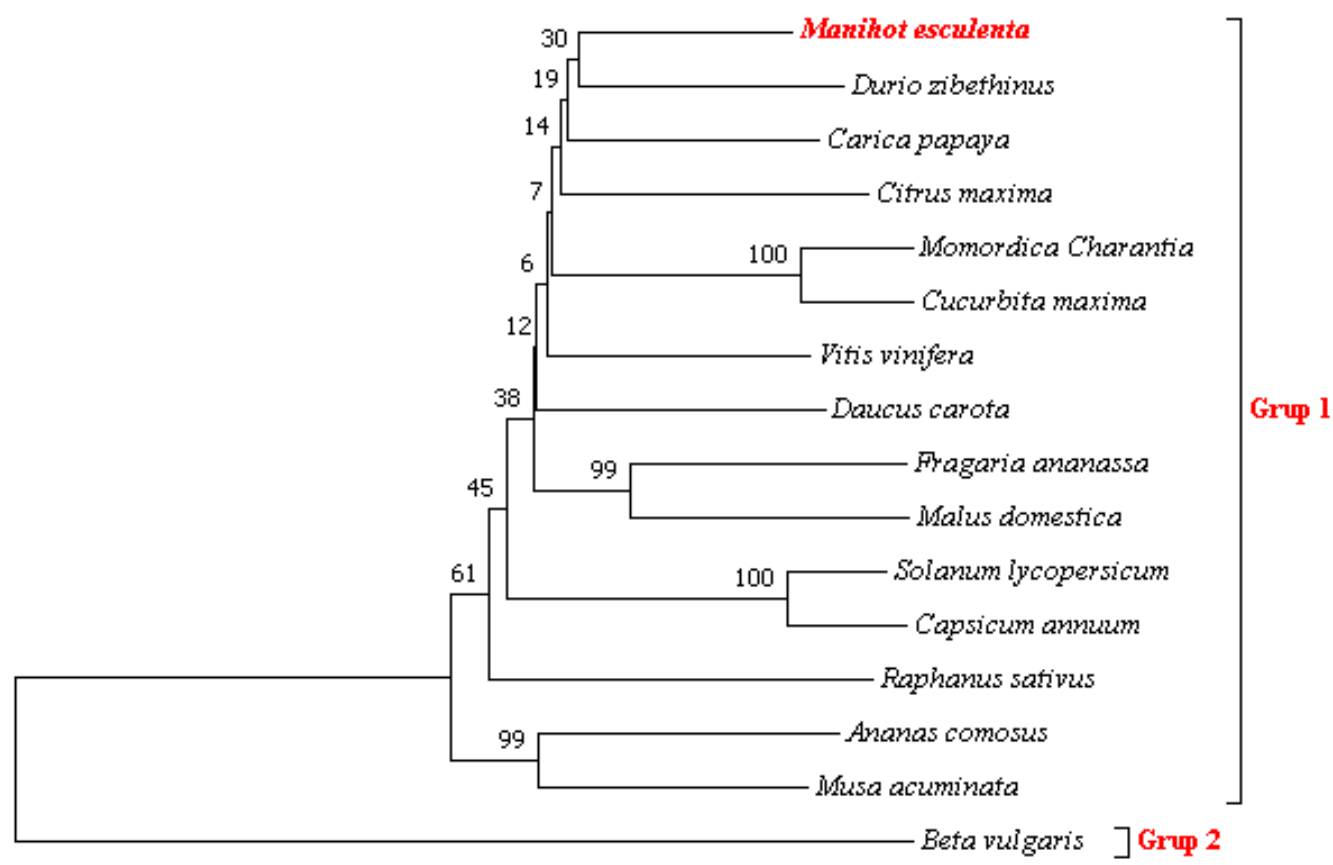

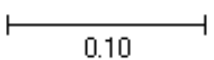

(A)
(B)

Figure 1. (A) The nucleotide gene Lcy $\alpha$ phylogenetic tree of plants. Phylogenetic construction using the neighbor-joining method and bootstrap analysis (500 replicates) using the Tajima-Nei model in MEGA 7 software. (B) The protein gene Lcy $\alpha$ phylogenetic tree of plants. Phylogenetic construction using the neighbor-joining method and bootstrap analysis (500 replicates) in MEGA 7 software.

Figure 1 (A), shows the nucleotide sequence of the Lcy a Manihot esculenta gene does not have close kinship with other plants even in the same group. Beta vulgaris is the plant that is the most distant relative to the overall analysis of phylogenetic trees. Figure 1 (B) shows that the protein sequence of Lcy a Manihot esculenta has the closest kinship to the Lcy a Durio zibenthinus gene even though it has a bootstrap value of 30 . In the phylogenetic B group 2, Beta vulgaris is the plant with the most distant relatives from the overall analysis phylogenetic tree. The relationship between Durio zibenthinus morphologically and taxonomy is closely related to Manihot esculenta. From the results of the nucleotide phylogenetic (figure 1 A) Manihot esculenta is closely related to Durio zibenthinus even though it is still in one group. The second result of the phylogenetic tree proves that nucleotide and protein phylogenetic trees are different. 

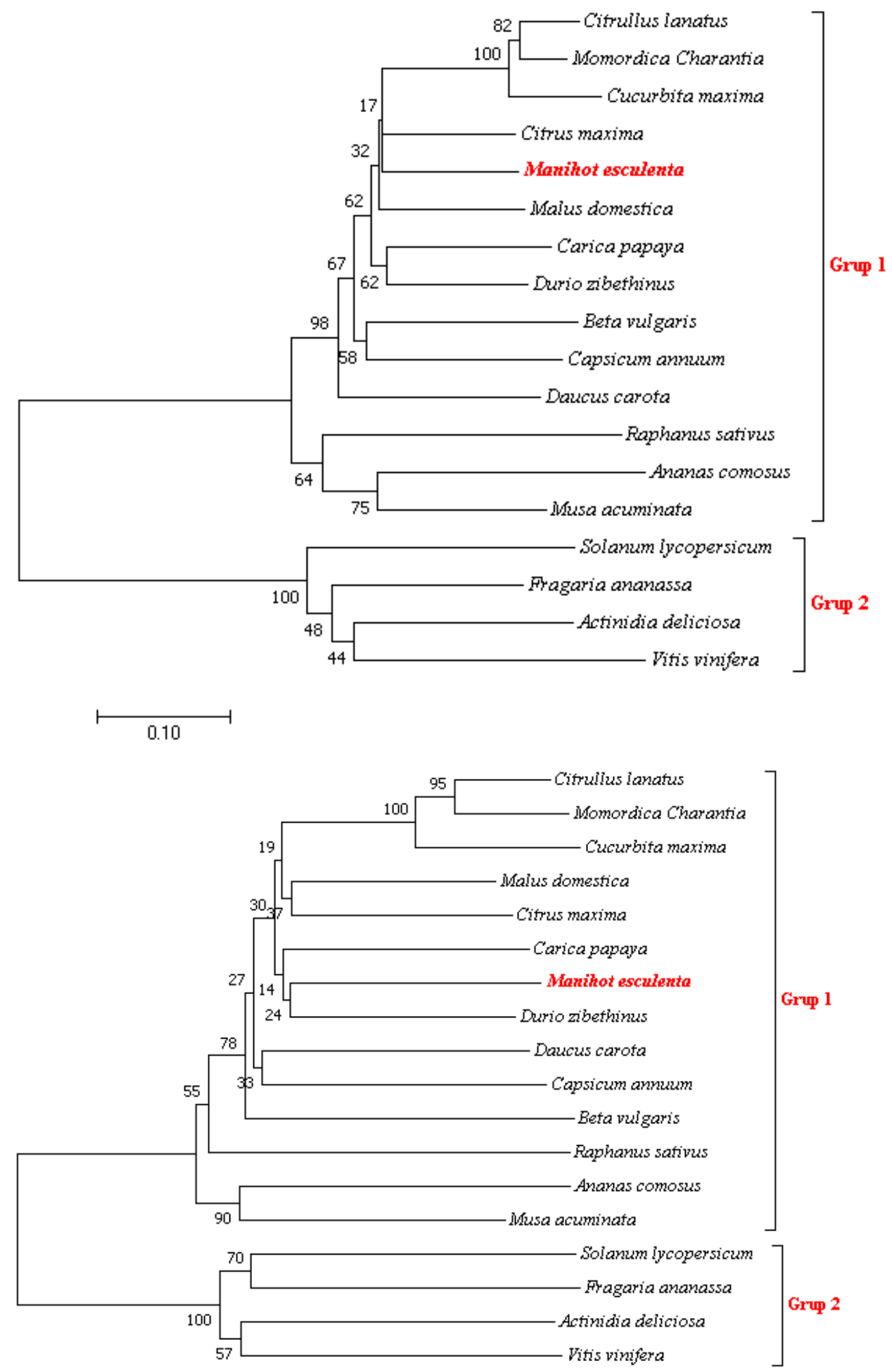

$\longmapsto$

(A)

14 IEKSAKTA: Berkala IImiah Bidang MIPA 
Figure 2. (A) The nucleotide gene Lcy $\beta$ phylogenetic tree of plants. Phylogenetic construction using the neighbor-joining method and bootstrap analysis (500 replicates) using the Tajima-Nei model in MEGA 7 software. (B) The protein gene Lcy $\beta$ phylogenetic tree of plants. Phylogenetic construction using the neighbor-joining method and bootstrap analysis (500 replicates) in MEGA 7 software.

Figure 2 (A), shows the nucleotide sequence of the Lcy $\beta$ gene Manihot esculenta has the closest ancestry to the gene Lcy b Citrus maxima. Solanum lycopersicum, Vitis vinifera, Fragaria ananassa and Actinidia deliciosa are the most distant group of plants from the overall phylogenetic analysis. Figure 2 (B), shows the protein sequence of the Lcy $\beta$ gene Manihot esculenta has the closest kinship to the protein of the Lcy $\beta$ gene Durio zibethinus, Solanum lycopersicum, Vitis vinifera, Fragaria ananassa and Actinidia deliciosa is the plant group that is the closest to the overall analysis phylogenetic.

There are differences in ancestry in nucleotide phylogenetic trees and phylogenetic trees of Lcy $\alpha$ gene proteins. This can be caused by two factors. First, proteins are obtained from the results of the transcription process of DNA into mRNA and the translation of mRNA into proteins that are expressed. Not all DNA will be transcribed into mRNA. Transcription results can be mRNA, rRNA, and tRNA. Second, the position of the start and stop codons are different .

Proteins can evolve at different rates due to intrinsic factors (repair mechanisms) and extrinsic factors (mutagens from the environment). Neutral mutations over the course of geological time will tend to accumulate in geneological lineages. So that there are differences in amino acid or nucleotide sequences among individuals .

Taxonomy of morphology Manihot esculenta including Familia Euphorbiaceae belonging to tubers. Ipomea batatas, Daucus carota, Beta vulgaris, Raphanus sativus, Amorphophallus campanulatus, Colocasia esculenta, and Dioscorea rotundata are several tuberous plants. Although Manihot esculenta belongs to the same grouping as some of these plants, it does not make Manihot esculenta has a kinship relationship in terms of its molecular. This proves that kinship in morphology cannot be a reference in its molecular relationships. Even the kinship of gene phylogenetic results is different from the kinship of the results of phylogenetic protein genes.

\section{Conclusion}

Phylogenetic trees nucleotide sequences and Lcy $\alpha$ and Lcy $\beta$ gene proteins Manihot esculenta have significant differences. Morphological kinship cannot be a reference for molecular relationships.

\section{References}

[1] Bendich, A. . 1990. Carotenoids y el sistema inmune, Química y biología: 323-35.

[2] Britton, G. . 1995. Structure and properties of carotenoids in relation to function, FASEB J, 9: 1551- 58.

[3] Cameron, K. M. . 2005. Leave it to the Leaves: a Molecular Phylogenetic Study of Malaxideae (Epidendroideae, Orchidaceae), Am. J. Bot., 92: 1025-32.

[4] Carvalho, L. J., Marco AV Agustini, James V Anderson, Eduardo A Vieira, Claudia RB de Souza, Songbi Chen, Barbara A Schaal and Joseane P Silva.

15 IEKSAKTA: Berkala IImiah Bidang MIPA 
2016. Natural variation in expression of genes associated with carotenoid biosynthesis and accumulation in cassava (Manihot esculenta Crantz) storage root BMC Plant Biology, 16: 133.

[5] Eddy, N. Q., Essien, E., Ebenso, E. E., dan Ukpe, R. A. 2012. Industrial Potential of Two Varieties of Cocoyam in Bread Making, J. Chem., 9: 451-64.

[6] Hartati, N. Sri, Hani Fitriani, Supatmi, Enny Sudarmonowati. 2012. Karakter Umbi Dan Nutrisi Tujuh Genotip Ubi Kayu (Manihot esculenta), Jurnal Agricola, 2.

[7] Hasyim, Ashol dan M. Yusuf. 2007. Ubi Jalar Kaya Antosianin Pilihan Pangan Sehat. In www.puslittan.bogor.net. Bogor: Puslitbangtan.

[8] Karnjanawipagul, P. W. Nittayanuntawech, P. Rojsanga and L. Suntornsuk. 2010. Analysis of $\beta$-Carotene in Carrot by Spectrophotometry, Mahidol University Journal of Pharmaceutical Science, 37: 8-16.

[9] Prabhala, R. H., H.S. Garewal, F.L. Meyskens, and R.R. Watson. 1990. Modulación de Immuno en humanos causado por caroteno y vitamina A, Nutr. Resolución, 10: 1473-86.

[10] Purwono. 2009. Klasifikiasi Pengelompokan Ubi kayu (Balai Besar Penelitian Pengembangan Pasaca Panen: Bogor).

[11] Stansfield, William, Raul Cano, and Jaime Colome. 2006. Schaum's Easy Outlines: Biologi Molekuler dan Sel (Erlangga: Jakarta).

[12] Suyamto, S. d. M. . 2009. Kesiapan Teknologi Mendukung Peningkatan Produksi Kedelai dan Ubi Kayu, Prosiding Inovasi Teknologi kacang-kacangan dan umbiumbian mendukung kemandirian pangan dan kecukupan energi, 16: 50.

[13] Vinolina, N. S. . 2009. Biosintesis Senyawa Karotenoid, Jurnal Penelitian Bidang Ilmu Pertanian, 7: 148 - 54.

[14] Yuwono. 2005. Biologi Molekular (Erlangga: Jakarta). 